\title{
VILLA, Marco Antonio. Vida e morte no sertão: história das secas no Nordeste nos séculos XIX e XX.
}

Paulo Henrique $M$ artinez UNESP - Assis

São Paulo: Ática, 2000, 269 pp.

Onde resideo interesse de um livro sobre a história das secas no nordeste do Brasil,nos dois últimos séculos? As secas constituem uma realidade presente, atuante nos dias de hoje, como no passado. E isto já bastaria para uma boa recepção ao livro de $M$ arco Antonio Villa, não trouxesse o volume outras tantas qualidades, e também problemas. 0 que faz de Vida e morteno sertão uma obra não apenas necessária, mas original e instigante, pelo que oferece, pela ajuda que fornece na compreensão do tema e pelo que faz pensar. $0 \mathrm{im}$ pacto provocado pela leitura é comparável àquele de Estação C arandiru, do médico D rauzio Varela, uma vez que ambos expõem as chagas e a indiferença da sociedade e do Estado, no Brasil, diante das mazelas sociais. Este sabor de livro-denúncia, temperado com demonstrações da negl igência,incúria, violência, cor rupção, manipulação e clientelismo reinantes, decorre da observação, em perspectiva temporal extensa, quase duzentos anos, da ação "reparadora" do Estado brasileiro nos momentos de seca. Villa não aborda a estrutura econômica e social nordestina, sob a qual se abate a calamidade,a mesma que produz e reforça seus efeitos, mas rastreia a ação de órgãos dos governos estaduais e federal, registrando o comportamento e a conduta das elites sociais e dos dirigentes políticos naquela região. A leitura de Vida e morte no sertão pode ser enriquecida, ainda, com outras publicações recentes, tais como Seca e poder: entrevista com Celso Furtado, da Fundação Perseu Abramo (1998), 0 "D ossiê N ordeste seco", organizado pelo geógrafo Aziz Ab'Saber para a revista Estudos Avançados (IEA/USP, no 36, 1999), e A invenção do N ordeste e outras artes, de Durval M uniz de Albuquerque (Cortez/M assangana, 1999).

A criatividade inventiva do autor foi capaz de suplantar a aridez intelectual que caracterizou as iniciativas governamentais na passagem dos quinhentos anos da viagem de Cabral. A realização da pesquisa contou com 0 apoio do Instituto Teotônio Vilela, ligado ao PSD B, que veio somar sua participação à de outras entidades similares, como a Fundação Perseu Abramo, ligada 
ao PT, e o Instituto Tancredo Neves, ao PFL. Distantes de desempenhar um papel de think tank nesses partidos, a preocupação que cada um deles, eà sua maneira, demonstra em pensar e conhecer o país não deixa de ser louvável.

0 livro estuda as principais secas ocorridas no nordeste brasileiro, entre os séculos XIX eXX, até o governo do general Figueiredo (1979-1985). Uma questão incomoda o autor, e ele a perseguiu com denodo ao longo dos capítulos: 0 saldo de mortos com as sucessivas secas, de um lado, e o imobilismo das autoridades públicas e da sociedade, de outro. Em operações de mórbida matemática, Villa estimou em torno de três milhões de pessoas as vítimas fatais nesses dois sécu los. U m novo holocausto, equivalente a duas guerras do Vietnã. Eis porque o livro é portador de "uma triste história em que a morte rondou diuturnamente a vida dos sertanejos" (p. 13). A seca de 1877-1879, uma das mais terríveis, teria dizimado cerca de $4 \%$ da população nordestina, erigindo o Nordeste, desde então, em "região-problema". Já a morte, convertendo-se em personagem principal, comparecena abertura de todos os capítulos e no encerramento do livro. Ao fechá-lo tem-se a sensação de haver assistido a um espetáculo macabro, impressionante. Palco privilegiado para atuação da morte e dos desmandos parece ter sido o Ceará.N ão se sabe se pelas condições particulares daquele Estado ou se pelas condições de acesso e disponibilidade de fontes e documentação, há no livro um certo protagonismo cearense em várias das situações estudadas.

No conjunto ressalta um minucioso trabal ho de pesquisa, exemplar em qualidade de análise, dos dados coligidos, na reconstituição de contextos e conjunturas. Os efeitos das secas so bre a economia regional e os grandes prejuízos que ocasionam; o fenômeno das migrações, orientadas, ao longo do tempo, para quase todo o Brasil, com destaque para o Maranhão, Pará, Amazonas, São Paulo, Rio de Janeiro, Distrito Federal e capitais do Nordeste; 0 surgimento de expressões, personagens e situações próprias ao universo das secas, como "indústria da seca", a Sudene, os saques, retirantes, epidemias, frentes de trabal ho, entre outros. Cenários que abrem o leque de problemas correlatos para novas pesquisas, tais como o papel da imprensa, os efeitos das intervenções governamentais, os movimentos sociais, o universo cultural e o imaginário das secas, as ações da I greja e dos partidos, o Nordeste como "região-problema", o impacto sobre as comunidades agrárias ea história regional. Sea introdução de dromedários na região, na década de 1850, fez a esperança de superação dos problemas das secas recair antes nas costas desses animais do que na ação dos homens, nas décadas de 1950 e 1960, as repetidas tentativas de definir uma política de desenvolvimento para o Nordeste tornaram-se pregações no deserto. A “inação" dos homens e a inclemência da natureza regaram o canteiro dos discursos de identidade regional, tragando in- 
clusive o Estado da Bahia, até então, unidade avulsa na federação brasileira. Lástima o livro não incorporar o tratamento dispensado às secas sob os governos civis, afinal, Sarney e Collor foram "presidentes do Nordeste", e na década de 1990, quando o PSDB dirigiu o País. O Instituto Teotônio Vilela poderia, assim, refletir e extrair lições sobre o comportamento de seu próprio partido no governo e das ações que este desenvolveu para enfrentar as calamidades provocadas pelas secas, como a de 1998, por exemplo. Teria havido, nestes últimos anos, mudanças nos procedimentos administrativos de prevenção e reparação dos males? Vida e morte no sertão também desperta a cobiça por estudos comparativos. Em 1998, diante dos incên di os florestais em Roraima (não haveria outras situações semel hantes na região amazônica?) , a postura do governo federal diferiu ou se assemelhou àquelas estudadas neste livro? Eis uma questão quepede esclarecimentos.E alguma pesquisa,não uma história-catástrofe.

Onde reside, para os historiadores, o interesse de um livro sobre a história das secas no nordeste do Brasil, nos dois últimos séculos? 0 interesse pelo Nordeste é remoto e diversificado, conforme constatou a professora Suely Robles Reis de Queiroz, autora de uma H istoriografia do N ordeste (São Paulo. Secretaria da Cultura/Arquivo do Estado, 1979, Col. M onografias, 2), dado, por exemplo, o papel que aquela porção de terra ocupou na América portuguesa. Há, também, no livro de M arco Antonio Villa, esse curioso ponto de partida, a geografia, o espaço, as condições climáticas e as particularidades que resultam das interven ções humanas, produtoras das peculiaridades dessa "região", examinadas em suas dimensões propriamente temporais. Um encontro entre as preocupações da H istória e da Geografia que caminham, juntas e atentas, às relações entre Estado e sociedade no Brasil. Diante dos problemas que, acredita Villa, deveriam ser enfrentados, o da terra, com a real ização de reforma agrária e o estabelecimento de lavouras secas, e o da água, com o armazenamento e o uso social dos recursos hídricos, estariam plantados os "condottieri do atraso", a elite social e política nordestina. Eis, então, uma questão para os historiadores: "Os fatores de conservação transformaram o semi-árido em uma região aparentemente sem história, dada a permanência e imutabilidade dos problemas. Como se com o decorrer das dé cadas nada tivesse se alterado e o presente fosse um eterno passado. A cada se ca, e mesmo no intervalo entre uma e outra, milhares de nordestinos foram abandonando a região. Sem esperan ça de mudar a história das suas cidades, buscaram em outras paragens a solução para a sobrevivência das suas famílias. Foi nos sertões que permaneceu inalterado o poder pessoal dos coronéis, petrificado durante o populismo e pela migração de milhões de nordestinos para o sul"( p. 252, grifos meus). Como explicar esta persistência? De onde 
ela emerge e como se alimenta? O usaria dizer que nas respostas àquela situação encontram-se elos dessa corrente do passado. Uma rigorosa evasão das populações, de um lado, fazendo de cidades e roças fontes ininterruptas de mão-de-obra barata, e a reiteração cultural das elites sociais e políticas, por outro, transformando-as em ponto de sustentação política dos governos estaduais e federal, têm sido respostas que aprisionam os homens à realidade que querem evitar. É o que se depreende de uma leitura desse livro, amparada em Fernand Braudel. Foi por dever de ofício, que o ministro do interior do governo Figueiredo, M ário Andreazza,aspirante à presidência da República, fez perto de sessenta visitas ao Nordeste, entre 1979-1981? Curiosa, também, a omissão da esquerda brasileira perante as secas. O PCB, diz o autor, "omitiu-se politicamente durante os flagelos" e "nunca se dispôs a apresentar um programa para a região" (p. 253).

Uma última palavra, sobre a religiosidade nordestina. Vista, até pouco anos atrás, por segmentos políticos e intelectuais, como uma dentre outras rotas de fuga da seca, ao lado da migração para as cidades e outras regiões do Brasil e, no passado, o cangaço e a jagunçama, a devoção religiosa foi associada a comportamentos sociais passivos no Nordeste, onde Canudos e Caldeirão formariam exceções à regra. Contudo, ao renovar esper anças em dias me Ihores, chuvas, chegada de alimentos, terra, sobrevivência dos roçados, essa mesma religiosidade converte-se em fator de "promoção social" e de expectativa de uma sedentarização, em condições outras. Permitiria, então, entrever possi bilidades distintas daquelas "respostas", anteriormente referidas?

Resenha recebida em 12/2001. Aprovada em 05/2002. 